\title{
Mensagem Presidente da ABPol
}

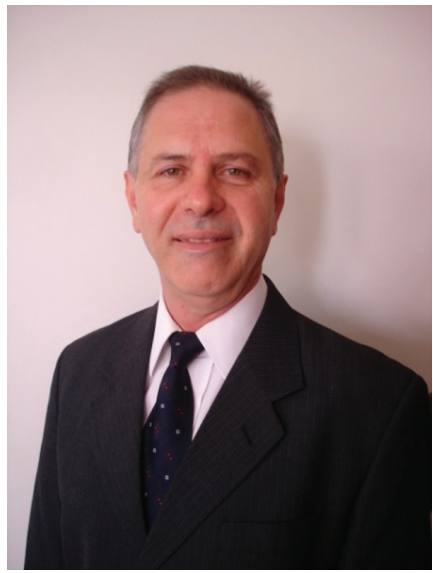

Fundada em 23 de Setembro de 1988, a Associação Brasileira de Polímeros - ABPol completou no mês passado 26 anos de existência! Parabéns a todos que contribuíram para com as atividades da ABPol em todo este período e o sucesso alcançado.

Ao longo destes anos a ABPol organizou 12 Congressos Brasileiros de Polímeros - CBPol, estando organizando no momento o $13^{\circ}$ CBPol que ocorrerá de 18 a 22 de Outubro de 2015 em Natal RN. Cada uma das ultimas edições do CBPol contaram com a participação de aproximadamente 1000 congressistas. Além dos Congressos Brasileiros de Polímeros, a ABPol organizou e/ou apoiou a realização de outros eventos nacionais e internacionais que permitiram a divulgação de trabalhos e a troca de experiências entre pesquisadores brasileiros e estrangeiros.

A ABPol nestes anos também manteve Comissões Técnicas em áreas tecnológicas de interesse da comunidade, realizou e está realizando no momento quatro Testes Interlaboratoriais com boa participação da comunidade industrial e também da comunidade acadêmica. Ofereceu ainda neste período um numero elevado de cursos de curta duração para a comunidade, contribuindo de forma significativa para a formação de recursos humanos.

Desde 1991 a ABPol edita a Revista Polímeros: Ciência e Tecnologia, que é um importante veiculo de divulgação de pesquisa e que tem melhorado continuamente seus indicadores, tal como fator de impacto. A revista atualmente aceita trabalhos em inglês, português e espanhol, permitindo a divulgação de trabalhos realizados por pesquisadores de diversos países.

Uma das importantes realizações da ABPol em 2014 é a organização do XIV Simpósio Latino Americano de Polímeros (XIV SLAP) e o XII Congresso Iberoamericano de Polímeros (XII CIP) de 12 a 16 de Outubro de 2014 em Porto de Galinhas - PE. O SLAP em conjunto com o CIP tem sido um dos mais importantes eventos da área de polímeros realizado na América Latina.

Desejamos que todos os participantes tenham um excelente congresso com frutíferas discussões e interações cientificas! 